\title{
Fecundity and spawning in squid of families Enoploteuthidae and Ancistrocheiridae (Cephalopoda: Oegopsida)*
}

\author{
V. V. LAPTIKHOVSKY \\ Atlantic Research Institute of Fisheries and Oceanography (AtlantNIRO), Dm.Donskoy st., 5, Kaliningrad, 236000 Russia
}

\begin{abstract}
SUMMARY: Reproductive system, potential fecundity (PF), relative fecundity (RF) and egg size (ES) were studied in Enoploteuthis anapsis, Abraliopsis atlantica, A.pfefferi (Enoploteuthidae) and Ancistrocheirus lesueurii (Ancystrocheiridae) at different stages of the life cycle. The reproductive system of mature females is 5-19\% of the total weight. In Enoploteuthidae PF is 4 000-30 000, RF is $1000-10000, \mathrm{ES}$ is 0.88-1.1 mm. In Ancistrocheirus the PF is $200000-800000$, RF is about 200 and ES is 1.75-1.85. An examination of advanced spawning and spent animals showed that females spawn more than $60-65 \%$ of potential fecundity. The reproductive strategy of the species studied is similar to that of the large nectonic squid families Ommastrephidae and Thysanoteuthidae.
\end{abstract}

Key words: Enoploteuthidae, squid, fecundity, spawning, eggs

\section{INTRODUCTION}

Enoploteuthid squids are the mass micronectonic squids of the epi-, meso - and bathypelagial of open tropical and subtropical waters. At night they occur in epipelagic layers. Females are larger than males; mantle length (ML) of adult animals varies from 25$35 \mathrm{~mm}$ in Abraliopsis, to $50-130 \mathrm{~mm}$ in Enoploteuthis. Life span is usually six months and occasionally one year (Nesis, 1987; Arkhipkin and Murzov, 1990; Hayashi, 1993; Young and Mangold, 1994 Arkhipkin, 1994, 1996).

Fecundity of this species species is poorly understood. Enoploteuthidae lack nidamental glands, that in representatives of other squid families produce a

\footnotetext{
*Received April 1, 1997. Accepted January 29, 1998.
}

gelatinous coat of egg mass, and spawns the single pelagic eggs during the long intermittent spawning (Nesis, 1985; Young and Harman, 1985; Young and Mangold, 1994). There are data on both egg dimensions and yolk oocyte number in the reproductive system of female Abralia andamanica, A.trigonura, Abraliopsis sp., Watasenia scintillans, Enoploteuthis chunii, Pterygioteuthis gemmata, Pyroteuthis addolux, (Amelekhina, 1983; Boucher, 1983; Okiyama, 1993; Young and Mangold, 1994) and on spawned egg dimensions in species of the genera Abralia, Abraliopsis, Watasenia and Enoploteuthis (Okiyama and Kasahara, 1975; Young and Harman, 1985; Young et al., 1987; Young and Mangold, 1994).

The large mesopelagic macroplanktonic Ancistrocheirus lesueurii (a single representative of the family Ancystrocheirinae closely related to Eno- 
ploteuthidae) has a flaccid and soft mantle and grows to ML $400 \mathrm{~mm}$ (Nesis, 1987). In the east tropic Atlantic, ML of mature females is $196-423 \mathrm{~mm}$, life span is about 2 years (Arkhipkin, in press). This species has nidamental glands and therefore can produce egg mass. To date, reproduction has not been studied.

The purpose of this paper is to investigate both fecundity and spawning in the squid of the former family Enoploteuthidae using the following species as examples: Enoploteuthis anapsis, Roper 1964; Abraliopsis atlantica Nesis, 1982 and Abraliopsis pfefferi Joubin, 1896 (Enoploteuthidae); Ancistrocheirus lesueurii Ferussac and d'Orbigny 1839.

\section{MATERIALS AND METHODS}

Fourteen Abraliopsis atlantica females of 17-35 $\mathrm{mm}$ ML were collected in open waters of the centraleast Atlantic by R/V "GRADIENT" (03.08.84, $\left.18^{\circ} 58 \mathrm{~S}, 4^{\circ} 44 \mathrm{~W}\right)$, "PROGNOZ" (16.04.85, 557S, $\left.6^{\circ} 00 \mathrm{~W}\right)$, and "SAULKRASTY" (05.02.87, 00 55S, $01^{\circ}$ 20W) (Fig. 1). Thirteen Abraliopsis pfefferi of 22$39 \mathrm{~mm}$ ML were caught in the north subtropic Atlantic by R/V "EVRICA" and "GIZHIGA" on 27.05.83 $\left(41^{\circ} 55 \mathrm{~N}, 60^{\circ} 09 \mathrm{~W}\right)$ and $02.09 .83\left(32^{\circ} 52 \mathrm{~N}, 33^{\circ} 24 \mathrm{~W}\right)$ (Fig.1). Females of Ancistrocheirus lesueurii (seven animals of 165-325 mm ML) were collected on 1014.07.95 off north-west Africa $\left(21^{\circ} 13-23^{\circ} 11 \mathrm{~N}\right.$, $17^{\circ} 08-17^{\circ} 36 \mathrm{~W}$ ), at a the bottom depth range of 330 $520 \mathrm{~m}$.. Four Enoploteuthis anapsis of 75-81 mm ML were caught on $12.07 .95\left(22^{\circ} 41 \mathrm{~N}, 17^{\circ} 21 \mathrm{~W}, 334-338\right.$ $\mathrm{m})$. The reproductive system of $A$. lesueurii and whole individuals of other species were stored in 6-8\% formaldehyde in sea water.

In the laboratory dorsal mantle length was measured to the nearest $1 \mathrm{~mm}$, total weight (TW), ovary weights, nidamental (in A. lesueurii) and oviducal gland weight, and stomach weight - all to the nearest $0.1 \mathrm{~g}$. These data were obtained in 1995-1996.

The maturity condition was assigned following the simplified ommasrephid scale (Burukovsky et al., 1977): 1) immature animals - in the ovary there are protoplasmic oocytes only; 2) maturing animals - in the ovary there are both protoplasmic and yolk oocytes, but there is no ripe egg in the reproductive system; 3) mature animals - there are ripe eggs in oviducts.

Due to the effect of preservation, the eggs when measured were not always perfectly symmetrical and, following Clarck (1934) to obviate any selection of

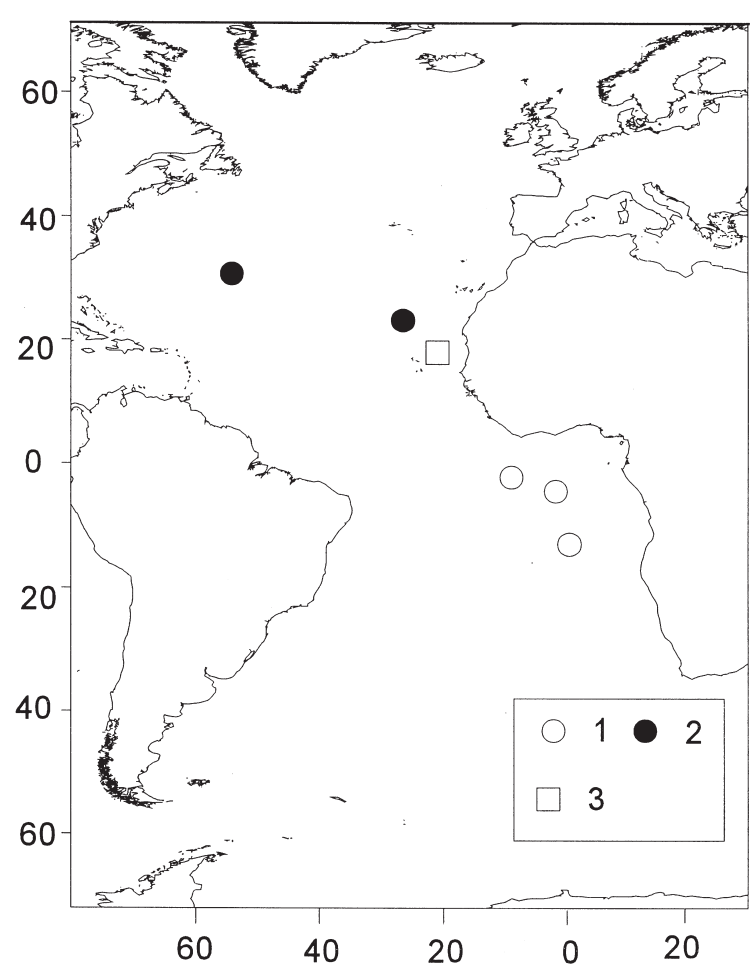

FIG. 1. - Location of samples of A. atlantica (1), A. pfefferi (2) E. anapsis and A. lesueurii (3).

the longest or shortest diameter, the micrometer was placed in a horizontal position in the eye-piece and the diameter parallel to the graduation on the micrometer measured. This average egg diameter was estimated in 50 ripe eggs. In some oocytes with a regular ovoid form, longest and shortest diameters were measured. To estimate oocyte number in the ovary, three 15-30 mg samples were taken. In the large females of $A$. lesueurii samples were taken from the ovary surface, from the ovary core, and from the intermediate layer. In animals of small-sized species samples were taken from the different parts of the gonad, because all three samples were equal to $10-50 \%$ of the whole ovary volume. It was possible to count all oocytes in each sample, because oocytes $<0.05 \mathrm{~mm}$ in diameter were absent in all animals investigated. As in other subadult and adult squids (Burukovsky et al., 1977; Knipe and Beeman, 1978; Sauer and Lipinski, 1990; Laptikhovsky and Nigmatullin, 1993; Lipinski and Underhill, 1995), no oogonia were found. The total number of oocytes in the reproductive system of prespawning females, therefore, was considered to be total oocyte production during ontogeny.

Potential fecundity (PF) was calculated as the sum of total oocyte number in the gonad and egg number in oviducts. Relative fecundity (RF) was 
estimated as the ration of PF to TW. An index of potential reproductive investment (PRI) was calculated as the product of RF and the weight of an individual ripe egg (Nigmatullin et al., 1981MS; Laptikhovsky and Nigmatullin, 1993).

\section{RESULTS}

\section{Enoploteuthis anapsis}

Two of the four examined females (ML 75 and $80 \mathrm{~mm}$ ) were mature, probably spawning. Another female (ML $77 \mathrm{~mm}$ ) was in advanced spawning condition and the fourth (ML $81 \mathrm{~mm}$ ) was spent.

The first three females (ML 75-80 mm) had remnants of the old spermatangia attached to their bodies behind the nuchal cartilage. The mature females had two oviducts filled with ripe eggs. Both the advanced spawning and spent females had only the left oviduct. Moreover, the spawning animal had only one (left) oviductal gland whilst the spent female had both oviducal glands.

In mature females with both oviducal glands present, the reproductive system was $15.9 \%$ and $18.1 \%$ $\mathrm{TW}$, of which the ovary was $5.2-8.4 \%$ and the oviducal glands 4.5 and $5.6 \%$. Size distribution of oocytes in the ovaries of mature females was uni- modal with a peak corresponding to the small protoplasmic cells (Fig.2). In the advanced spawning female this peak shifted from 0.1 to $0.3 \mathrm{~mm}$ due to the continuous protoplasmic growth of the early oocytes. In this animal, the posterior part of the ovary and it's left border (app. 20\% of the gonad volume) were covered by a thick whitish substance and contained numerous ripe eggs and large $(>0.7$ $\mathrm{mm})$ yolk oocytes. No protoplasmic oocyte were found in this substance. The share of the yolk oocytes in the mature female gonads was 17.7$29.6 \%$, in the advanced spawning animal it was estimated at $15-16 \%$, despite an increase of dimensions of protoplasmic oocytes

There were no oocytes in the remnants of the ovary of the spent female. These remnants consisted of unstructured pale grey slim around the axial blood vessel. Probably all "post-spawning" oocytes were resorbed. Thirteen eggs were in the oviduct.

Potential fecundity of mature females was 34500 (ML $80 \mathrm{~mm}$ ) and 23500 (ML $75 \mathrm{~mm}$ ). In the advanced spawning animal it was estimated at about 20000 . Relative fecundity was approximately $1500-$ 2000 egg/g, PRI - 0.6-0.9.

Ripe egg dimensions were 1.0-1.1 × 0.85-0.9 $\mathrm{mm}$ (average egg diameter 0.96-0.98 $\mathrm{mm}$, egg weight $0.44-0.45 \mathrm{mg}$ ). The maximum egg number in oviducts was 2800 (ML $80 \mathrm{~mm}$ ).

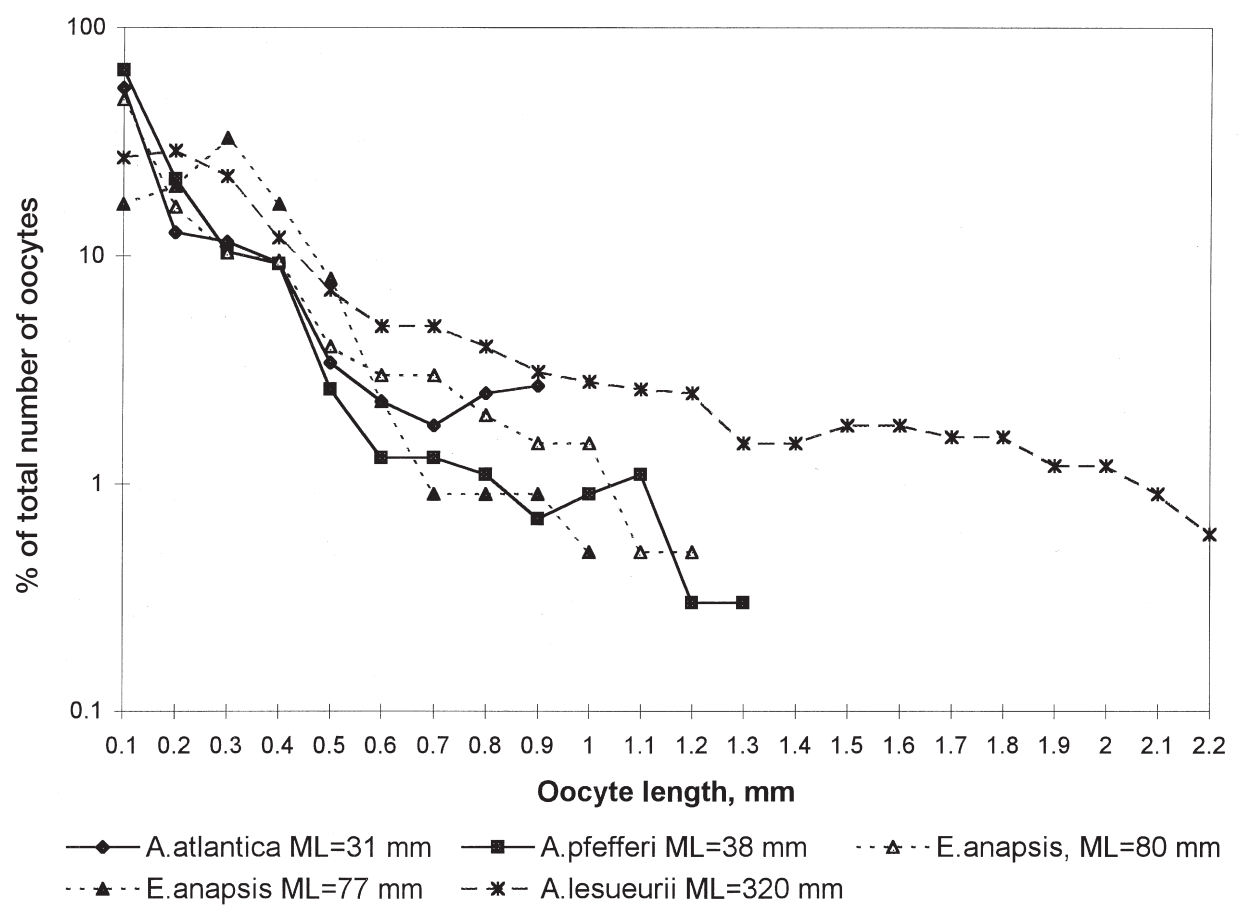

Fig. 2. - Size distribution of oocytes in mature squid. 

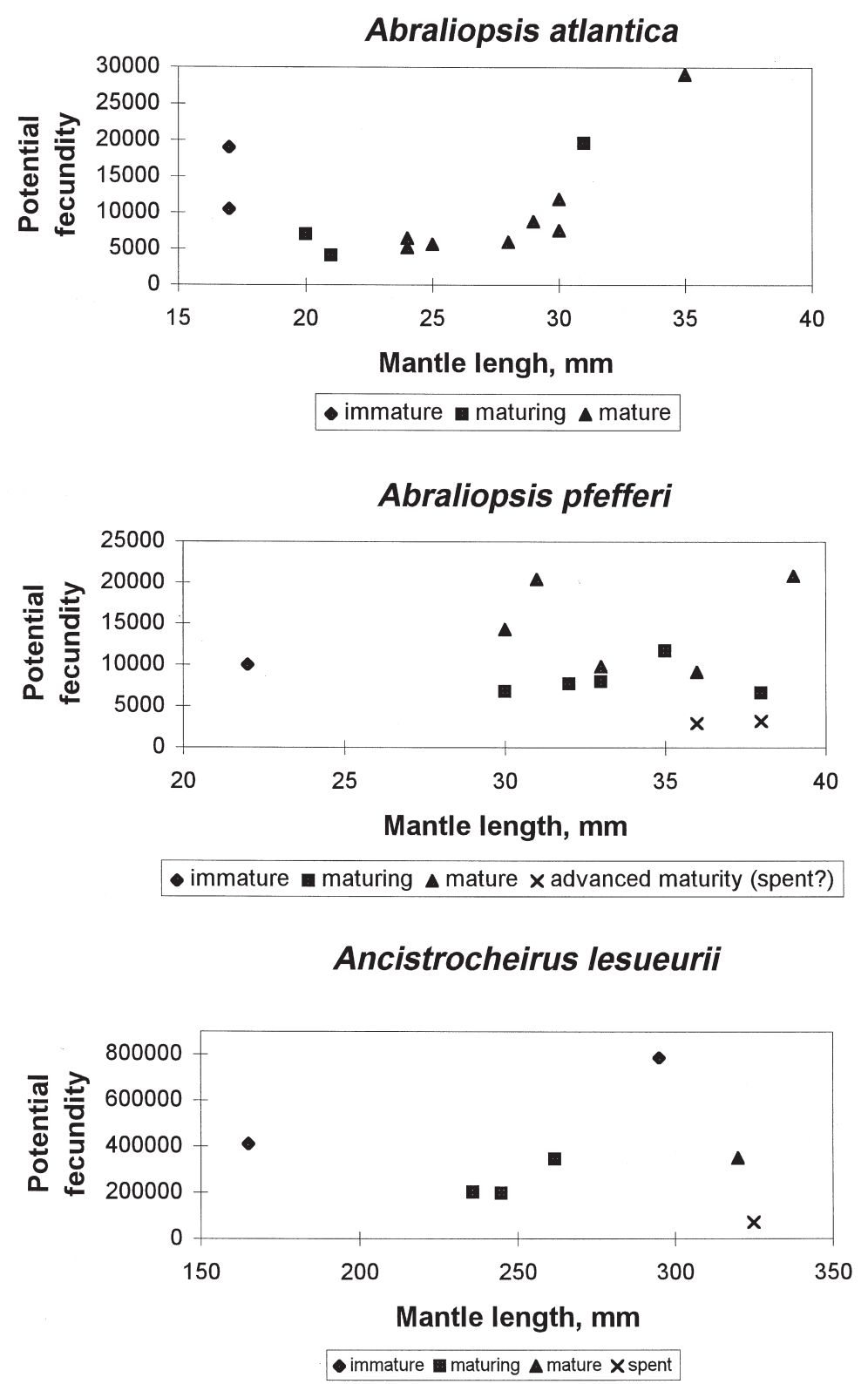

Fig. 3. - Potencial fecundity in A. atlantica, A. pfefferi and A. lesueurii.

There were no visible differences in body shape between the advanced spawning and spent females on the one hand, and normal mature females on the other hand. The stomach of the spent female was filled by food and there were traces of food in stomachs of other animals, indicating that this species goes on to feed after the end of spawning.

\section{Abraliopsis atlantica}

In mature females, the reproductive system is 11$19.5 \%$ TW (mean $14.2 \%$ ) of which ovary was $4.3-$ 13.9 (mean 9.1\%) and oviductal glands 2.1-6.3 (mean 3.2\%). Protoplasmic oocytes of size 0.1-0.2 $\mathrm{mm}$ dominated in gonads in all stages of ontogeny including maturity (Fig.2). Yolk oocytes represented in mature squid $2.6-18.2 \%$ (mean $8.6 \%$ ) of the total oocyte stock in the ovary.

There were up to 400 eggs in oviducts. Egg dimensions were $1.0 \times 0.75-0.8 \mathrm{~mm}$ (average diameter 0.88-0.91 mm, egg weight - 0.26-0.32 mg).

Potential fecundity increased with ML from 4000 to 29000 (Fig.3). In maturing animals RF was $5900-10800 \mathrm{egg} / \mathrm{g}$ (mean $8800 \mathrm{egg} / \mathrm{g}$ ), in mature animals RF was 3800-8700 egg/g (mean 4900 egg/g), PRI was 1.2-2.6 (mean 1.5). The type of the 
spermatophore attachment during copulation was the same as in E.anapsis.

There were no advanced spawning and spent animals.

\section{Abraliopsis pfefferi}

The weight of the whole reproductive system in mature squids was 5.2-17.2\% TW (mean 12.0\%). Ovary was $4.5-14.2 \%$ (mean $8.8 \%$ ), oviducal glands $1.1-3.5 \%$ (mean $2.3 \%$ ). Size distribution of oocytes in ovaries and attachment of the spermatophores during copulation were the same as in A. atlantica. Yolk oocytes represented in mature squids 7.3$30.9 \%$ (mean $18.8 \%$ ) of the total oocyte stock in the ovary.

In oviducts there were up to 130 eggs of $0.9-1.0 \times$ 1.1-1.5 mm (average diameter 1.0-1.1 mm, egg weight $0.66-0.71 \mathrm{mg}$ ). Potential fecundity in prespawning and mature squids was 6500 - 21000. In maturing animals $\mathrm{RF}$ was 2400-8000 egg/g (mean $4400 \mathrm{egg} / \mathrm{g}$ ), in mature animals it was $1000-3900 \mathrm{egg} / \mathrm{g}$ (mean 2400 egg/g). PRI was 0.7-2.8 (mean 1.7).

Potential fecundity of the most advanced spawning females (ML 31 and $38 \mathrm{~mm}$ ) was 2900 and 3200. Their life stage was assumed not only owing to the low PF, but from the unusually high abundance of the empty resorping follicles in the ovaries. No obvious degenerative changes were observed.

\section{Ancistrocheirus lesueurii}

Size distribution of oocytes was similar to that of the other species studied with a single exception: yolk oocytes were larger following larger ripe eggs. Protoplasmic oocytes dominated in the gonad during all of ontogeny. In the single mature female of $320 \mathrm{~mm}$ ML, a share of the yolk oocytes varied from $60 \%$ (the ovary surface) to 28 (the ovary core), the average being $35-40 \%$.

Weight of reproductive system in the mature female was $17.8 \% \mathrm{TW}$, of which the ovary was $6.3 \%$, the oviducal glands was $6.4 \%$, the nidamental glands $3.1 \%$, and the oviducts with eggs $2 \%$.

Potential fecundity in prespawning animals varied from 195000 to 790000 . Relative fecundity of the maturing squid (ML $292 \mathrm{~mm}$ ) was $430 \mathrm{eggs} / \mathrm{g}$, and $230 \mathrm{eggs} / \mathrm{g}$ in the mature female. PRI was 1.7 .

Ripe egg dimensions were 2.0-2.2 $\times 1.5-1.6 \mathrm{~mm}$ (average diameter 1.75-1.85 mm, egg weight - 3.15$3.5 \mathrm{mg}$ ). There were about 7000 ripe eggs in the oviducts of mature female.
A spent female of $325 \mathrm{~mm}$ ML was collected $\left(11.07 .95 ; 21^{\circ} 47 \mathrm{~N}, 17^{\circ} 27 \mathrm{~W} ; 400-520 \mathrm{~m}\right.$, horizon $50-100 \mathrm{~m})$ in a damaged condition and without a head. The post-spawning condition was assigned due to the small gonad (ovary weight $3.5 \mathrm{~g}$ in contrast to $95.0 \mathrm{~g}$ in the mature female of the similar ML) and presence of 57 ripe eggs in oviducts.

In the laboratory investigation no yolk oocytes larger $0.9 \mathrm{~mm}$ were found in the ovary. Remnants of empty follicles of 1.2-2 mm length were scarce. The share of yolk oocytes was some $50 \%$. Almost all protoplasmic oocytes were degenerating. Their covers remained intact, but became slightly wrinkled and nothing was seen inside. Residual fecundity was approximately 70000. No traces of slim was in the ovary.

In all squids studied no copulation traces were found on the nuchal cartilage, buccal membrane, inside of the mantle cavity or on the outer surface of body.

\section{DISCUSSION}

In mature ovaries of all species studied, there were oocytes at all stages of both protoplasmic and vitelline growth. Small protoplasmic oocytes significantly dominated without any obvious modal size in the yolk accumulating cells. It was seen that the vitelline growth of oocytes and ripe egg production occurs continuously through the mature stage of ontogeny as it does in the large nectonic oceanic squid families Ommastrephidae and Thysanoteuthidae (Burukovsky et al., 1977; Harman et al., 1989; Nigmatullin and Laptikhovsky, 1994; Laptikhovsky, 1995; Nigmatullin et al., 1995).

Relative weight of the reproductive system (10$30 \% \mathrm{TW}$ ) is the same as that in Ommastrephidae (Laptikhovsky, 1995) and a bit higher than in Thysanoteuthidae (Nigmatullin et al., 1991). Absence of nidamental glands is compensated for by an increase of the ovary weight (average 8-9\% TW in contrast to 5-6\% in Ommastrephidae and Thysanoteuthidae). Oviducal glands are much larger (2-3\% TW) than in ommastrephid squids $(0.2-0.6 \%)$, but lighter than in Thysanoteuthis (4-5\%).

Ancistrocheirus lesueurii is a single species possessing nidamental glands, which are twice lighter than oviducal ones. A similar weight relation was found in Thysanoteuthis (Nigmatullin et al., 1991) in contrast to the ommastrephids, whose nidamental gland weight exceeds oviducal gland weight by a factor of 10-20 (Laptikhovsky, 1995). Presumably, this can mean a similarity of pecularities of egg 
mass formation in both species with a leading role of oviducal glands.

In all enoploteuthids studied, the eggs were small: their largest diameter was $1.0-1.5 \mathrm{~mm}$ (average diameter - $0.88-1.1 \mathrm{~mm}$ ) which is similar to data in the literature for other representatives of the Enoploteuthidae (Amelekhina, 1983; Boucher, 1983; Burgess, 1982; Okiyama, 1993; Young and Mangold, 1994) as for other open ocean cephalopods: Ommastrephidae and small epipelagic octopod Argonauta spp (Hochberg et al., 1992; Nigmatullin and Laptikhovsky, 1994; Laptikhovsky, 1995; Nigmatullin et al., 1995). Probably this means that an egg size of $0.7-1.2 \mathrm{~mm}$ (and related hatchling size) is optimal for the cephalopod species spawning in the epipelagial zone of the open ocean.

Our estimations of PF in the genera Abraliopsis were similar to that of A.trigonura (Young, Mangold, 1994) and Watasenia scintillans (Hayashi, 1993). In Enoploteuthis anapsis PF exceeds an estimation for E.chuni (5500-13000) by a factor of 3-4, despite larger eggs: in E.chuni egg size is $0.75 \times$ $0.69 \mathrm{~mm}$ (Hayashi, 1993). Unfortunately it is not clear, what kind of oocytes have been counted in the Pacific species. Thus, in Enoploteuthidae and Pyroteuthidae PF varies from several thousand to several dozen thousand eggs.

The residual PF in advanced spawning A. pfefferi and E.anapsis suggests that during the breeding period the female releases most of the initial total oocyte stock. In the single spent Ancystrocheirus lesueurii there were about 70000 oocytes from the initial stock of $200000-400000$. Thus $60-85 \%$ of $\mathrm{PF}$ was spent. A similar level of utilization is peculiar to some squids and cuttlefish Sepia officinalis (Boletzky, 1987; 1988; Susumu, 1987; Laptikhovsky and Zorikova, 1992; Laptikhovsky and Nigmatullin, 1993).

In micronectonic enoploteuthid squids RF is similar to that observed in the genera Sthenoteuthis, Hyaloteuthis, Eucleoteuthis which have RF of 1000$7000 \mathrm{egg} / \mathrm{g}$ (Laptikhovsky, 1995). The index of reproductive investment is a little higher in enoploteuthids due to the larger eggs: in oceanic ommastrephids the average egg size is usually $0.75-0.9 \mathrm{~mm}$.

A comparison of the fecundity and the egg number in oviducts shows that spawning is prolonged and intermittent when oviducts in all species are filled and emptied at least 10 times. A large number of ripe eggs in oviducts (usually hundreds and up to more than 2000 in E. anapsis) contrasts with a release of single eggs during spawning. Probably this egg accumulation is related to the daily rhythmics of spawning, and moreover, presumably spawning occurs not every night as in Abralia trigonura (Young and Mangold, 1994).

Spawning and post-spawning degeneration of somatic tissue is an usual phenomena in many nektonic squid (Hamabe, 1963; Laptikhovsky and Nigmatullin, 1993; Jackson and Mladenov, 1994). Prior to spawning, ommasrephid females cease to feed and the stomachs of spent animals are always empty (Laptikhovsky and Nigmatullin, 1992; Bower, Sakurai, 1996). In S. officinalis, during the weeks immediately preceeding natural death, a dramatic drop in hunting success occurs, related to the degeneration of the central nervous system. The last days of life the cuttlefish has no interest to prey (Chichery and Chichery, 1992). Active feeding of Enoploteuthidae during spawning may be caused by a necessity of the further food supply to egg production. Similar feeding on spawning grounds was found in Loligo vulgaris reynaudii (Sauer and Lipinski, 1991).

Reproductive strategies of the micronektonic enoploteuthid squids are analogous to those of other inhabitants of the open ocean pelagial - large nectonic ommastrephid squids. Both families are clearly expressed r-strategists with the same type of ovary development, egg size of 0.8-1.1 mm and RF of $1000-9000 \mathrm{egg} / \mathrm{g}$. Micronectonic squid have a slightly higher PRI and much shorter life cycle that is related to the extreme shift of the reproductive strategy in the r-direction. The closest reproductive strategy is peculiar to the ommastrephids Hyaloteuthis pelagica and small form of Symplectoteuthis oualaniensis without photophore (Nigmatullin and Laptikhovsky, 1994). This is a reproductive strategy of nektonic squids of an open ocean with significant diurnal vertical migrations.

\section{ACKNOWLEDGEMENTS}

I am very grateful to Drs. A.I. Arkhipkin and Ch.M. Nigmatullin for valuable comments and both anonimous referees. The research was supported in part by the International Science Foundation under Grant No NNF000.

\section{REFERENCES}

Amelekhina A.M. - 1983. Some aspects of the life history of the Indian ocean squid Abralia andamanica Goodrich, 1896. Taxonomy and ecology of Cephalopoda. Zoological Institute of the 
USSR Academy of Sciences, Leningrad. (In Russian): 108-109. Arkhipkin A.I. and Murzov S.A. - 1990. Age and growth pattern of the micronectonic squid, Abraliopsis atlantica (Enoploteuthidae). Biol. Morya, (11): 19-25 (In Russian with English abstract).

Arkhipkin A.I. - 1994. Age, growth and maturation of the squid Enoploteuthis leptura (Oegopsida, Enoploteuthidae) from the central - east Atlantic. J. Moll. Stud., 60: 1-8.

Arkhipkin A.I. - 1996. Age and growth of the squid Abraliopsis pfefferi (Oegopsida: Enoploteuthidae) from the Central-East Atlantic based on statolith microstructure. Sci. Mar., 60 (2-3): 325-330.

Arkhipkin A.I. - in press, 1997. Age and growth of a mesopelagic squid Ancistrocheirus lesueurii (Oegopsida, Ancystrocheiridae) from the central-east Atlantic based on statolith microstructure. Mar. Biol.

Boletzky S.v. - 1987. Fecundity variation in relation to intermittent or chronic spawning in the cuttlefish, Sepia officinalis L. (Mollusca, Cephalopoda). Bull. Mar. Sci., 40 (2): 382-388.

Boletzky S.v. - 1988. A new record of long continued spawning of Sepia officinalis (Mollusca, Cephalopoda). Rapp. Comm. int. Mer Medit., 31 (2): 257.

Boucher L.M. - 1983. Aspects of reproduction in some enoploteuthid squids from Hawaiian waters. Veliger 26 (2): 106-112.

Bower J.R. and Y. Sakurai. - 1996. Laboratory observations on Todarodes pacificus (Cephalopoda: Ommastrephidae) egg masses. Amer. Malacol. Bull., 13 (1/2): 65-71.

Burgess L.A. - 1982. Four new species of squid (Oegopsida, Enoploteuthis) from the central Pacific and a description of adult Enoploteuthis reticulata. Fish. Bull., 80 (4): 703-734.

Burukovsky R.N., G.V. Zuev, Ch.M. Nigmatullin and M.A. Tsymbal. - 1977. Methodical bases for working out the scales of reproductive system maturity in squid females Sthenoteuthis pteropus (Cephalopoda, Ommastrephidae) taken as an example. Zool. Zhur., 56 (12): 1781-1791 (In Russian with English abstract)

Chichery M.P. and R. Chichery. - 1992. Behavioural and neurohistological changes in aging Sepia. Brain Res., 574 (1-2): 77-84.

Clarck F.N. - 1934, Maturity of the California sardine (Sardina caerulea), determined by ova diameter measurements. Fish. Bull., 42: 1-49.

Hamabe M. - 1963. Exhaustion process of the genital organs of common squid Ommastrephes sloani pacificus. Bull. Jap. Sea Reg. Fish. Res. Lab., 11: 53-63.

Harman R.F., R.E. Young, S.B.Reid, K.M. Mangold and R.F Hixon. - 1989. Evidence for multiple spawning in the tropical oceanic squid Sthenoteuthis oualaniensis (Teuthoidea, Ommastrephidae). Mar. Biol., 101 (4): 513-519.

Hayashi S. - 1993. Growth and maturation of the firefly squid, Watasenia scintillans (Berry) in Toyama Bay and adjacent waters of the sea of Japan. In: Okutani T., O'Dor R.K. Kubodera T. (eds), Recent advances in cephalopod fisheries biology, pp. 173-178. Tokay Univ. Press, Tokyo.

Hochberg F.G., M. Nixon and R.B. Toll. - 1992. Order Octopoda Leach, 1818. In: M.J.Sweeney, C.F.E.Roper, K.M.Mangold M.R.Clarke and S.v.Boletzky (eds), "Larval" and juvenile cephalopods: a manual for their identification, pp. 213-279. Smiths. Contrib. Zool. (613), Smiths. Instit. Press, Washington D.C.

Jackson G.D. and P.V. Mladenov. - 1994. Terminal spawning in the deepwater squid Moroteuthis ingens (Cephalopoda: Onychoteuthidae). J. Zool. Lond., 234: 189-201.
Knipe J.H. and R.D. Beeman. - 1978. Histological observations on oogenesis in Loligo opalescens. Fish. Bull., 1969: 23-33.

Laptikhovsky V.V. - 1995. The mechanisms of formarion of the reproductive strategies in squid family Ommastrephidae: fecundity, duration of embryogenesis and mortality. Ph.D.Thesis., Kaliningrad, 209 p. (In Russian).

Laptikhovskii V.V. and A.A. Zorikova. - 1992. Fertility and some features of reproductive biology of squid Todarodes angolensis in waters of Namibia. Russian J. Mar. Biol., 18: 172-179.

Laptikhovsky V.V. and Ch.M. Nigmatullin. - 1993. Egg size, fecundity and spawning in females of the genus Illex (Cephalopoda: Ommastrephidae). ICES J. Mar. Sci., (50): 393403.

Lipinski M.R. and L.G. Underhill. - 1995. Sexual maturation in squid: quantum or continuum? South Afr. J. Mar. Sci., 15: 207223.

Nesis K.N. - 1985. Oceanic cephalopod molluscs: distribution, life forms and evolution. Moscow, Nauka Press. (In Russian).

Nesis K.N. - 1987. Cephalopods of the World. T.F.H. Publications, Neptune City.

Nigmatullin Ch.M. and V.V. Laptikhovsky. - 1994. Reproductive strategies in the squids of the family Ommastrephidae (preliminary report). Ruthenica, 4 (1): 79-82.

Nigmatullin Ch.M., A.I. Arkhipkin and R.M. Sabirov. - 1991. Structure of the reproductive system of the squid Thysanoteuthis rhombus (Cephalopoda: Oegopsida). J. Zool., Lond. 224: $271-283$

Nigmatullin Ch.M., A.I. Arkhipkin and R.M. Sabirov. - 1995. Age, growth and reproductive biology of diamond-shaped squid Thysanoteuthis rhombus (Oegopsida: Thysanoteuthidae). Mar. Ecol. Prog. Ser., 124: 73-87.

Okiyama M. - 1993. Kinds, abundance and distribution of the oceanic squids in the Sea of Japan. In: Okutani T., O’Dor R.K. and Kubodera T. (eds) Recent Advances in Cephalopod Fisheries Biology. Tokay Univ.Press., Tokyo: 403-415.

Okiyama M. and S. Kasahara. - 1975. Identification of the so-called "common squid eggs" collected in the Japan Sea and adjacent waters. Bull. Jap. Reg. Fish. Res. Lab., 26: 35-40.

Sauer W.H. and M.R. Lipinski. - 1990. Histological validation of morphological stages of sexual maturity in chokker squid Loligo vulgaris reynaudii d'Orb. (Cephalopoda: Loliginidae). South Afr. J. mar. Sci., 9: 189-200.

Sauer W.H. and M.R. Lipinski. - 1991. Food of the squid Loligo vulgaris reynaudii (Cephalopoda: Loliginidae) on their spawning grounds off the Eastern Cape, South Africa. South Afr. J. mar. Sci., 10: 193-201.

Susumu S. - 1987. Life history of the oval squid, Sepioteuthis lessoniana in Kaminato and adjacent waters of central Honshu, Japan. J. Tokyo Univ. Fish., 74 (2): 67-105.

Young R.E. and R.F. Harman. - 1985. Early life history strategies of enoploteuthid squids (Cephalopoda: Teuthoidea: Enoploteuthidae) from Hawaiian waters. Vie Milieu, 35 (3-4): 181201.

Young R.E., R.F. Harman and K.M. Mangold. - 1987. The common occurrence of oegopsid eggs in near-surface oceanic waters. Pac. Sci., 39 (4): 359-366.

Young R.E. and Mangold K.M. - 1994. Growth and reproduction in the mesopelagic boundary squid Abralia trigonura. Mar. Biol., 119 (3): 413-421.

Scient. ed.: J.M. Gili 